\title{
BIOECOLOGICAL OBSERVATIONS ON A PIGMY \\ LOCUST, POTUA SABULOSA HANCOCK \\ (TETRIGIDAE: ORTHOPTERA)*
}

\author{
By S. Y. Paranjape and A. M. Bhalerao \\ Post Graduate Research Centre, Department of Zoology, \\ Modern College, S'nagar, PUNE-411 005 (M.S.India).
}

\section{INTRODUCTION}

Faunistic studies of the tetrigids of Indian subcontinent have been made by Kirby (1914) and Hancock (1915). These are of great fundamental value but dealing necessarily with the taxonomic description. The biology and ethoecology of many species of tetrigids are largely unknown. Moreover, there is practically no published research on the bioecology of Indian tetrigids.

The present paper deals with bioecological observations on a tetrigid, Potua sabulosa Hancock. This work is based on the field observations of well over six years, in certain localities in Maharashtra State (M.S.) a south-western region of India. It forms a part of 'Survey, Taxonomy and Etho-ecological studies on Tetrigids,' an on-going research project (F.1-20/79-PP) supported by Indian Council of Agricultural Research, New Delhi.

Potua sabulosa belongs to sub-family Cladonotinae. The species was first taxonomically described by Hancock (1915) and the habitat was recorded as Venna valley, Mahabaleshwar (M'shwar), Dist. Satara. In our extensive survey, we collected $P$. sabulosa not only from Venna valley but also from other valleys in M'shwar, namely Blue valley, Krishna valley and Koyana valley. In the region under survey, we also collected these insects from certain other localities of Western Ghats of Maharashtra, such as, Pratapgad, Panchgani in Dist. Satara and Sinhagad, in Dist. Pune. Our collection of $P$. sabulosa from these new localities constitutes a first record.

Materials ANd Methods

Samples of living Potua were collected from the above mentioned localities. The insects are somewhat difficult to locate on account of

*Manuscript received by the editor November 12, 1984. 
the small size and the ability to blend with the surrounding. However, being sluggish these are easy to catch, once detected. After collection, the specimens were transferred to insect cages containing their natural food. These cages were then brought to the research centre for further investigations. The insects were maintained in the cages by simulating the natural conditions to the extent possible.

Field observations were periodically made to gather the data in relation to habitat, seasonal variations in the population size and of bioecological behaviour.

Measurements of body parts of male and female Potua were made with calibrated eye-piece gratings, of a zoom type trinocular dissecting microscope.

\section{Observations ANd Discussion}

P. sabulosa Hancock is smallest of the tetrigids studied in our laboratory. It can be aptly called the 'Pigmy locust'(Fig. 1). Table 1 summaries the information about the localities where it has been observed, so far. These localities generally have lush forests in common, as well as year around humid and relatively cool climate.

Furthermore, it may be noted here that in the surveys undertaken of certain altitudinally near-similar localities in Western Ghats such as Lonavala-Khandala (Dist. Pune, Alt. 733 \& $630 \mathrm{mts}$ respectively) Matheran (Dist. Raigad, Alt. $833 \mathrm{mts}$ ) and Trimbak (Dist. Nasik, Alt. $950 \mathrm{mts}$ ) the authors could not, so far, come across $P$. sabulosa. This presumably means that besides altitude certain other ecological conditions could be playing some role in the distribution of this insect.

Typically, the insect is found on the walls of buildings, large stems of plants, in the crevices of rocks, fencings and similar other places which are covered with bryophytes, especially the moss. Its sitting posture is typically like that of other locusts. The body colour is usually dull brown to gray, very similar to the soil and rocks of the Deccan plateau of Western Ghats. Insects are usually very well camouflaged with their habitat. The pronotum is high, arched, slightly roof-like, wrinkled and with tubercles. It is as long as the abdomen in both the sexes (Fig. 2). Hind femora are large, stout, marginally serrated and tuberculate on the outer side. Table 2 gives the measurements of various body parts of the male and female 


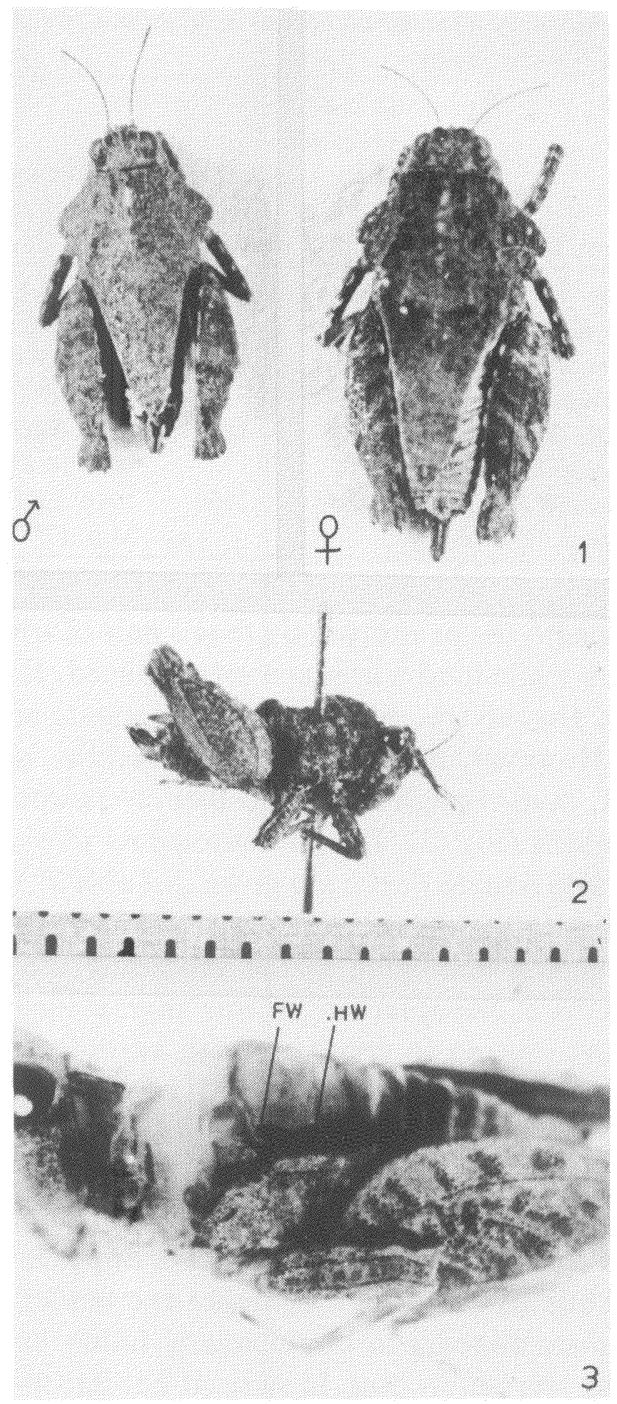

Fig. 1-3, Potua sabulosa Hancock. 1. Dorsal view of male $(\times 6)$ and female $(\times 6)$. 2. Lateral view of male. 3 . Lateral view, with pronotum removed to show left vestigial fore wing (FW) and hind wing (HW). 
Table 1. Climatological information of certain localities in which Potua sabulosa Hancock has been reported by us.

\begin{tabular}{|c|c|c|c|c|c|}
\hline Locality & Lat./ Long. & $\begin{array}{c}\text { Altitude } \\
\text { (Height } \\
\text { from } \\
\text { M.S.L. } \\
\text { in mts) }\end{array}$ & $\begin{array}{c}\text { Average } \\
\text { Rainfall } \\
\text { mm/anum. }\end{array}$ & $\begin{array}{c}\text { Average } \\
\text { Max. and } \\
\text { Min. Temp. }\end{array}$ & $\begin{array}{c}\text { Average } \\
\text { Humidity }\end{array}$ \\
\hline M'shwar & $\begin{array}{l}\text { Lat. } 17^{\circ} 56^{\prime} \mathrm{N} \\
\text { Long. } 73^{\circ} 40^{\prime} \mathrm{E}\end{array}$ & 1573 & 6226 & $\begin{array}{l}\text { Max. } 24.1^{\circ} \mathrm{C} \\
\text { Min. } 13.6^{\circ} \mathrm{C}\end{array}$ & $70 \%$ \\
\hline Pratapgad & $\begin{array}{l}\text { Lat. } 18^{\circ} 0^{\prime} \mathrm{N} \\
\text { Long. } 74^{\circ} 22^{\prime} \mathrm{E}\end{array}$ & 1185 & 7250 & $\begin{array}{l}\text { Max. } 25^{\circ} \mathrm{C} \\
\text { Min. } 16^{\circ} \mathrm{C}\end{array}$ & $68 \%$ \\
\hline Panchgani & $\begin{array}{l}\text { Lat. } 17^{\circ} 55^{\prime} \mathrm{N} \\
\text { Long. } 73^{\circ} 49^{\prime} \mathrm{E}\end{array}$ & 1464 & 1865 & $\begin{array}{l}\text { Max. } 35.6^{\circ} \mathrm{C} \\
\text { Min. } 16.1^{\circ} \mathrm{C}\end{array}$ & $70 \%$ \\
\hline Sinhagad & $\begin{array}{l}\text { Lat. } 18^{\circ} 22^{\prime} \mathrm{N} \\
\text { Long. } 73^{\circ} 45^{\prime} \mathrm{E}\end{array}$ & 1436 & 1100 & $\begin{array}{l}\text { Max. } 33^{\circ} \mathrm{C} \\
\text { Min. } 17^{\circ} \mathrm{C} \\
\end{array}$ & $70 \%$ \\
\hline
\end{tabular}

Potua. Underneath the pronotum there is a pair of triangular, thick and scaly elytra while hind wings are very reduced. Hancock (1915) has mentioned that elytra are minute and elongate and hind wings are wanting. However, after careful observations we have found that the wings, even though thickened like elytra and vestigial, are unfailingly present (Fig. 3). The measurements of elytra and these wings in male and female Potua are given in Table 2. Therefore, this insect comes under the category of 'brachypterous form', although certain other genera belonging to the subfamily Cladonotinae are apterous in nature. Meopterism of this pigmy locust favourably indicates its distribution to relatively high altitudes. Potua usually crawls when disturbed and rarely jumps. It can jump to a distance of about 25 to $35 \mathrm{~cm}$.

The insects feed on humus along with bryophytes like moss (Funaria sps.), algae, fungi and lichens present in the vicinity of the habitat. From laboratory observations there appears to be a strong preference for humus as well as for smaller and tender plants such as moss. $P$. sabulosa appears to be unusually hardy and can survive periods of long starvation both in natural habitat as well as under laboratory conditions. For example, our laboratory observations indicate that the adults can survive total starvation for a period of more than two months. However, the nymphs lose their vitality very rapidly, when kept starved in the cages.

Potua, like other tetrigids, shows well defined sexual dimorphism. Copulating pairs can be observed immediately after the initial mon- 
Table 2. Average measurements in $\mathrm{mm}$ of various body parts in 10 specimens of Potua sabulosa Hancock

\begin{tabular}{lccccccc}
\hline & & \multicolumn{2}{c}{ Length } & \multicolumn{3}{c}{ Breadth } \\
Sex & Body & Pronotum & $\begin{array}{c}\text { Hind } \\
\text { femur }\end{array}$ & $\begin{array}{c}\text { Fore } \\
\text { wings }\end{array}$ & Hind & $\begin{array}{c}\text { Fore } \\
\text { wings }\end{array}$ & Hind \\
wings & (Elytra) & wings \\
\hline Male & 6.0 & 5.5 & 4.2 & 1.04 & 1.13 & 0.42 & 0.34 \\
Female & 8.0 & 6.5 & 5.0 & 1.13 & 1.25 & 0.46 & 0.38 \\
\hline
\end{tabular}

soon showers. The female Potua excavates small burrow at a depth of about $2 \mathrm{~mm}$ in the loose superficial soil or between the dense tufts or patches of moss and other bryophytes with the help of its ovipositor, and lays 23-25 eggs in a loose cluster. The eggs are smaller in size with very short and stubby chorionic filaments or 'horns'. These are laid in a more or less single layer. In this connection, it is interesting to note that in other tetrigids, such as Euscelimena harpago Serv. belonging to the semiaquatic subfamily Scelimeninae, the eggs have elongate filaments. Moreover, they are laid relatively deeper and the cluster is arranged in 3 to 4 tiers (Bhalerao \& Paranjape, 1984). Potua, brought to the laboratory and kept in cages provided with moist soil and moss, laid eggs in July-August as well as in April and May. However, in their natural habitat, we could find pigmy locusts laying eggs in July-August only. The hatching takes place in about 10-12 days at room temperature of $23^{\circ}$ to $25^{\circ} \mathrm{C}$. The early instars are minute, stumpy replicas of the adults.

The insect population is considerable immediately after monsoon and one can see 5-10 individuals per square meter. The population level gradually declines with the onset of summer until about late April, when practically no adult Potua can be observed in the exposed, dried out niches. However, when searched critically, very few adults can be located, hidden about 3 to $5 \mathrm{~cm}$ beneath the soil of the fence-walls. The pigmy locusts actually burrow to reach this relatively cool soil and remain in this condition, to tide over the hazardous summer season. This peculiar behaviour of the pigmy locusts has been observed by us for the first time. After two or three showers of monsoon, these insects once again come out into the open, copulate and lay eggs. The adults of the previous season then die, while the eggs hatch, and the life cycle of Potua continues.

During our extensive survey and collection of this tetrigid in various parts of Western Ghats, we came across some variations in the 
colour pattern, body size and in the nature of pronotum. This suggests that $P$. sabulosa shows some 'ecotypes' due to climatological or other ecological variations in these localities. Further studies on various interesting aspects of this insect are in progress.

\section{ACKNOWLEDGMENT}

The authors are grateful to ICAR New Delhi, for financial support and to Dr. N. C. Pant, Director, Commonwealth Institute of Entomology, London, for arranging for the determination of the insect by Mr. W. J. Reynolds, taxonomist, British Museum, London. The genus and species name was later confirmed by Dr. M. S. Shishodia, taxonomist, Zoological Survey of India, Calcutta. Thanks are due to the taxonomists. Thanks are also due to Shri Kamble for valuable help during survey; to Dr. H. V. Ghate in discussions, and photography; to A. D. G. Meteorology Department Pune, for giving the necessary data and to Prin. S. Y. Gambhir for providing facilities and giving encouragement.

\section{REFERENCES}

Bhalerao, A. M. And S. Y. Paranjape

1984. Bioecological studies on Euscelimena harpago Serv. International J. Ent. (In press)

HANCOCK, J. L.

1915. Indian Tetriginae (Acrydiinae). Rec. Indian Mus. 11: 55-137.

KIRBY, W. F.

1914. The Fauna of British India, including Ceylon and Burma. OrthopteraVol. I (Acrididae). Taylor and Francis, London, U.K. 

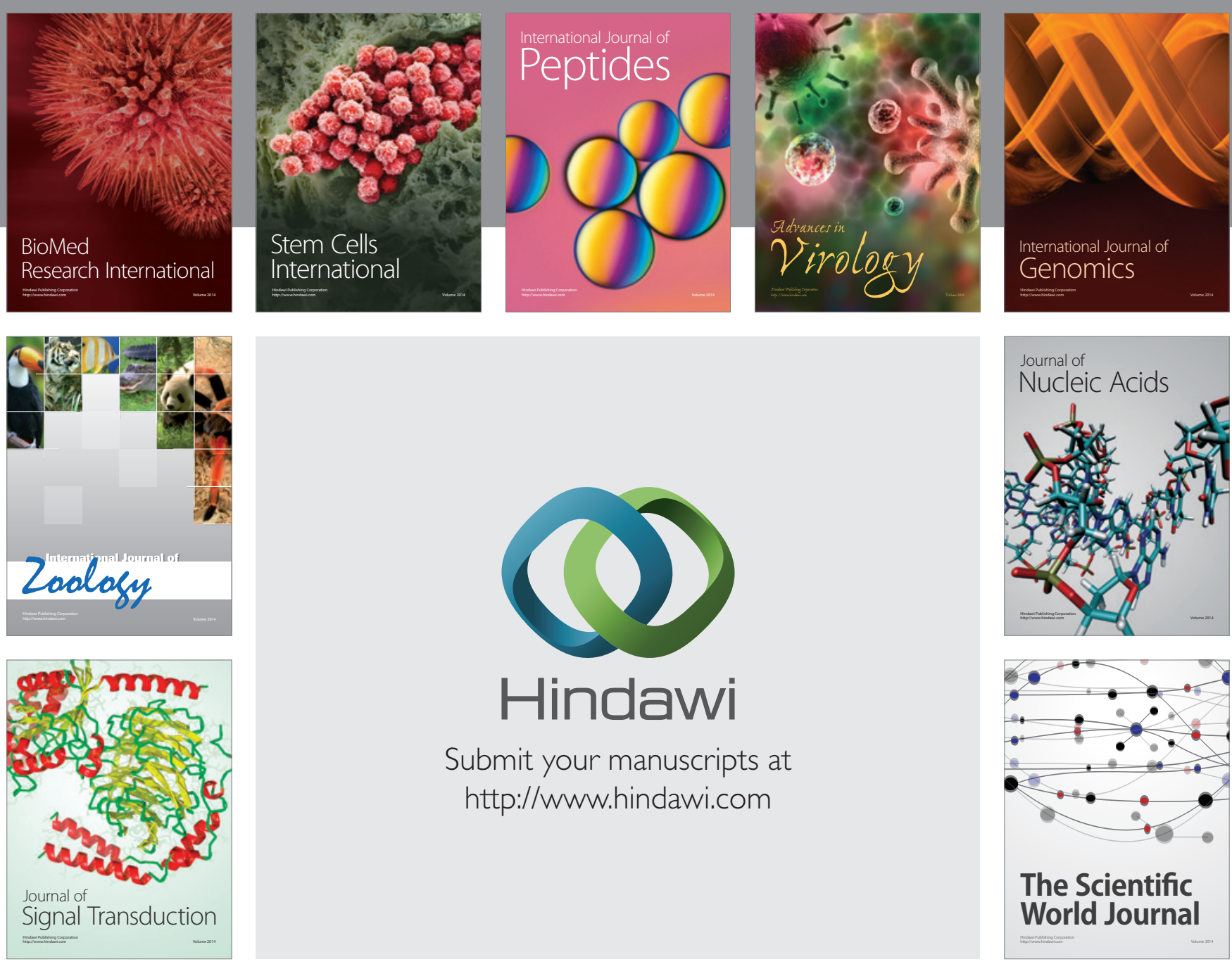

Submit your manuscripts at

http://www.hindawi.com
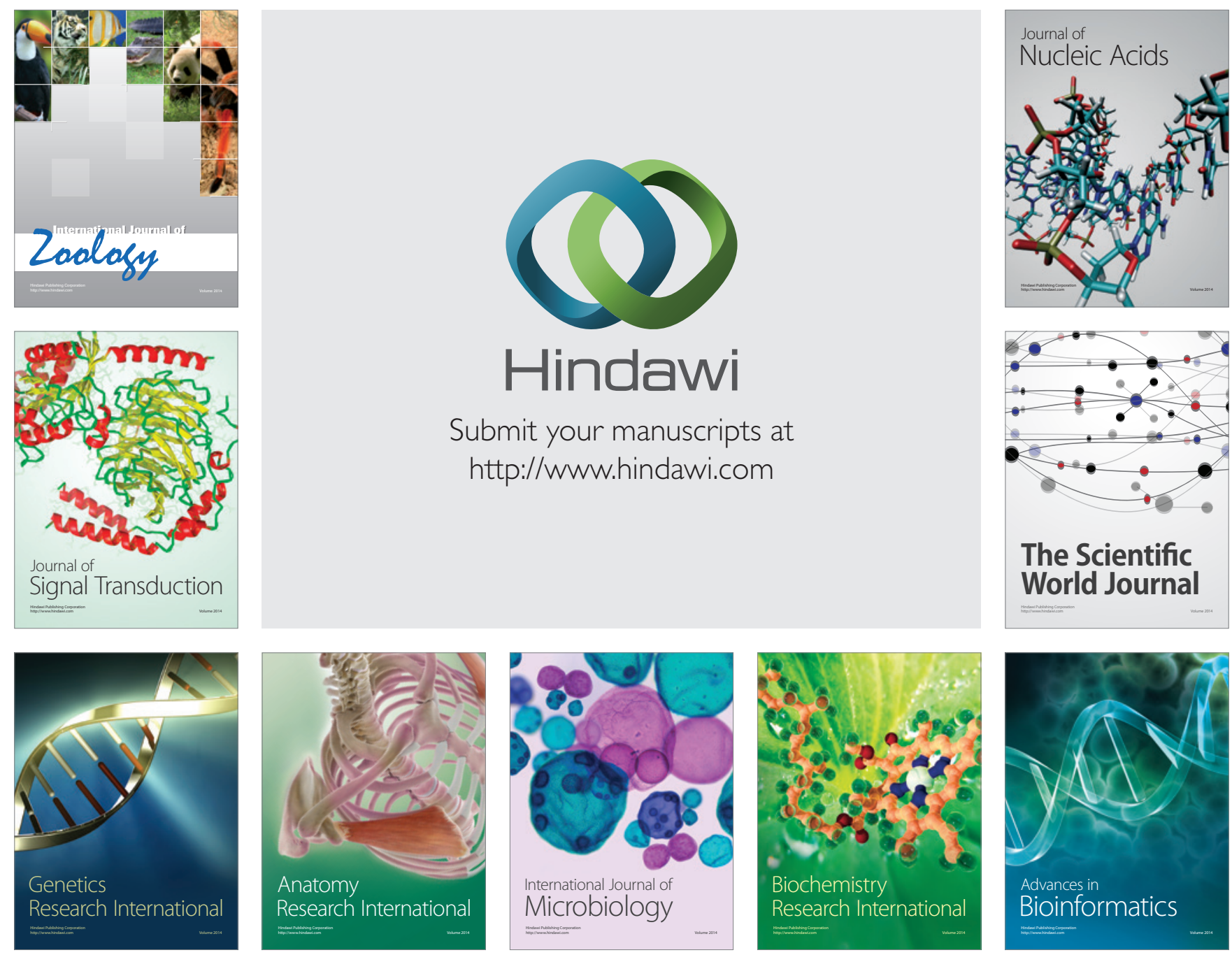

The Scientific World Journal
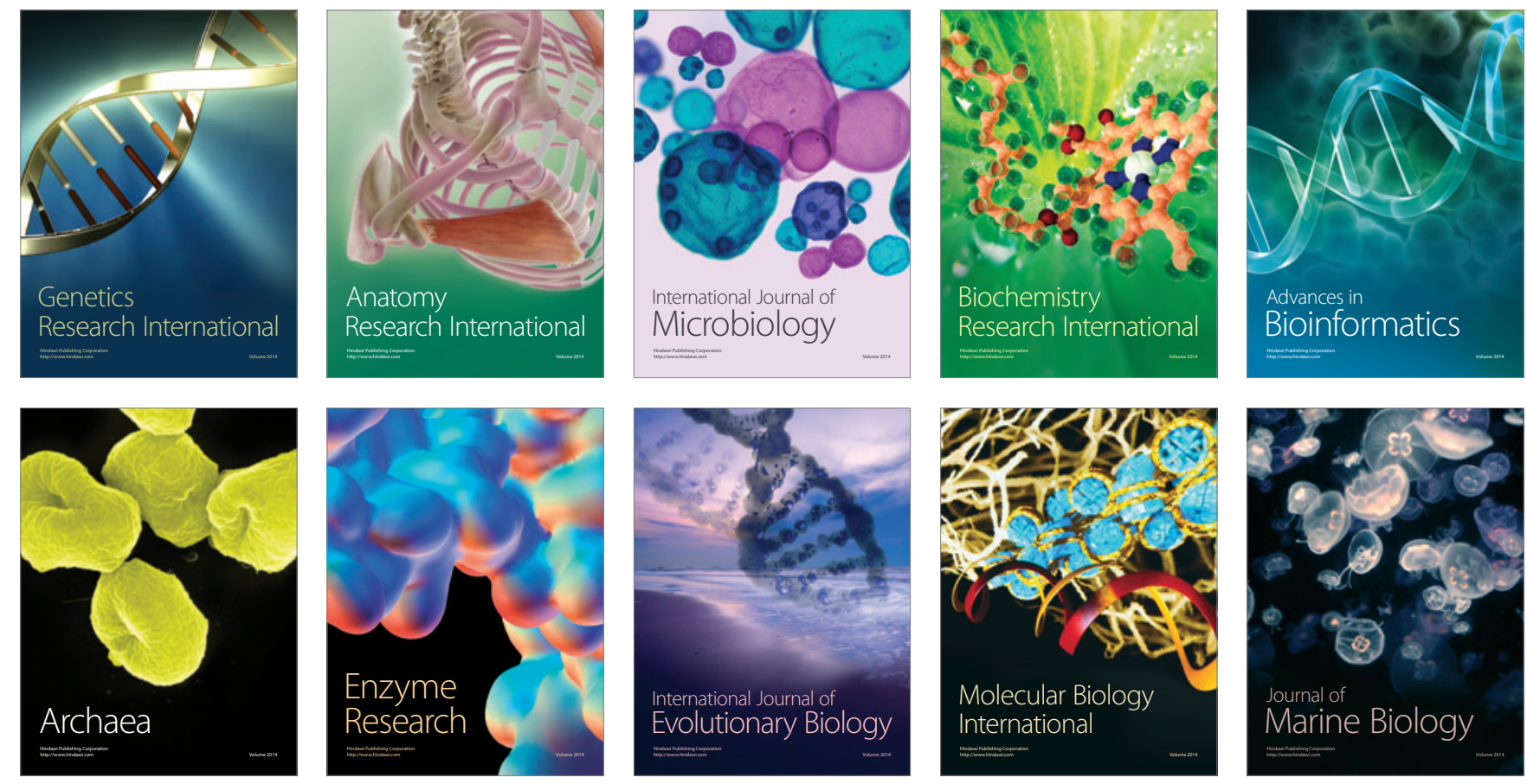